\title{
Agustí Bartra: en busca de la dimensión trágica*
}

\author{
¿Algunos datos biográficos?
}

¡Oh no, no! ¿Datos sobre mí mismo? De ninguna manera. De eso, querido Fernando, se cuidan los diccionarios, y no es cuestión ahora de entrar en competencia con ellos. Hay que dar a los diccionarios lo que es de los diccionarios. Saludémoslos, desde lejos. No me pidas que me equivoque sobre, o contra, mí mismo. Por otra parte, como sabes muy bien, mi esposa Anna publicó hace un par de años su Crónica de la Vida de Agusti Bartra, empezada el mismo día en que me conoció en Roissy-en-Brie, en 1939, después de haber salido yo del campo de concentración de Agde. La Crónica es mucho más que un libro de información sobre un hombre: es una obra de amor. Nunca escribiré mis Memorias: no podría ser el administrador de mis recuerdos, y cuando se trata de mis vivencias, es decir, de las imágenes esenciales del alma, la poesía se sirve de mí. Tal vez podría escribir de mi infancia luminosa y feliz de niño pobre, y de la casa de la familia en el Guinardó primero y luego en la Rambla de Sabadell. De mi infancia en Sabadell destacaría dos cosas: un baúl y la bocina de un fonógrafo. Un día descubrí en el desván de la casa un baúl lleno de libros de mi padre: Salgari, Guimerá, Haeckel, Amichatis, Víctor Hugo, etc. Pero el libro que siempre he recordado fue de una tal baroresa de Wilson. No tengo la menor idea acerca de qué trataba la obra y nunca he descubierto ningún rastro de la misteriosa baronesa de Wilson. Pero aquella noble de capa caída (porque se hospedó durante cierto tiempo en la modesta pensión que mis padres regentaron en la Rambla de Santa Mónica de Barcelona, donde nací) cuyo retrato constaba en el libro, se parecía, como descubrí más tarde, a Selma Lagerloff, -una de las iluminaciones de mi adolescencia, como Máximo Gorki- y era dueña de un tesoro: poseía 365 relojes. En los

* Entrevista a Agustí Bartra hecha por un alumno de doctorado de la Universidad de Maryland (EE.UU.) como trabajo académico, en octubre de 1969. Hasta ahora inédita. 
últimos tiempos no pagaba la pensión con dinero, sino con relojes... Ahora hablemos de la bocina de fonógrafo. Mi padre era a la sazón representante en Sabadell de las máquinas de coser Wertheim y, en la tienda, vendía además fonógrafos y discos. Un atardecer de invierno me mandó a un encargo: entregar una bocina de fonógrafo a una dirección que me apuntó en un pedazo de papel. La calle se encontraba en un barrio obrero, cerca del río Ripoll. Con la enorme corola de hojalata al hombro, me perdí en un barrio que conocía poco. Había caído la noche. Un poco asustado, me detuve a descansar junto a un muro muy bajo, rodeado de sombras. De pronto, apoyé la bocina sobre el muro, acerqué los labios a la embocadura y grité mi nombre con todas las fuerzas de mis pulmones, una y otra vez: ¡Agustíiiiiii...! Estaba como fascinado y me temblaban las piernas. Muchos años después comprendí que aquella noche por primera vez había gritado mi ser, con un inconsciente anhelo de afirmación. No recuerdo si pude entregar mi flor de hierro. Siempre que podía escapaba al campo. Me fascinaban las hormigas, las bellotas, los girasoles y los perros.

\section{¿Qué factores han influido sobre el escritor Agusti Bartra?}

Los seres y las cosas. Haber vivido a la intemperie, entre hermanos, y haber escuchado el canto de las savias y de la sangre. A veces sé que me ha ayudado el deseo de convertir aquella corola de hierro de mi infancia en un clarín solitario que convoque la solidaridad dispersa. Ha sido también un factor benéfico mi salud, a prueba de las lentejas de una guerra y dos campos de concentración. Haber sabido salir de lo terrible sin hacer del odio una profesión y, en cambio, haber podido vivir en las convicciones y fulgores del amor. En cierta manera escribí mi novela, La luna muere con agua para poder llegar a la palabra final.

- ¿Cuál es, Agusti?

- Aurora.

¿Podrías decirme algo sobre tu método de trabajo?

Dificilmente. Porque no tengo método. El trabajo creador, para mí, representa una lucha a brazo partido para forzar 
las esperas. Si elárbol del espíritu no se sacudiera, nunca caería la fruta. Pocas veces las palabras se apoderan de mí: he de ir a buscarlas a sus escondrijos y sacarlas con el látigo. "Chillen, putas", dijo de ellas Octavio Paz. Pero a veces también sucede que acuden como las bestias sumisas que rodearon a Orfeo. Voy siempre lleno de imágenes, visiones, ideas, proyectos, intuiciones confusas, misterios fragmentados, etc. que, cuando he terminado una obra, empiezan a agitarse dentro de mí hasta el momento en que uno de ellos se adelanta y, al escogerme con su poder, rechaza a la disponibilidad a todos los demás. Cuando empiezo una obra, mi único método es no soltar la presa, aunque vencerla me cueste tres mil noches de encarnizamiento. Cada obra exige una lucha distinta. Tardé veinte años en lograr la versión definitiva de las elegías que componen mi Ecce Homo, que tienen ochenta páginas impresas; La luna muere con agua fue escrita en un año y medio y Cartel para los muros de mi patria fue el canto de un mes. Siempre oscilo entre la fluencia y el estallido, entre las voces y las presencias, entre el latido y el rigor...

¿Cuál de tus obras consideras más lograda?

La que nunca podré escribir. Pero puedo decir algo de mis preferencias. Tengo una particular ternura por Cristo de 200.000 brazos. Es tal vez una especie de fidelidad a una circunstancia extrema e histórica que me marcó para siempre. Allí estaban Marsias y Calibán. Sigo enamorado de Démeter y de tres o cuatro figuras más de Odiseo, que escribí en los Estados Unidos hace veinte años. En algunos cantos de Marsias y Adila me encuentro con las sangres profundas en vilo. Ecce Homo y La luna muere con agua contienen, creo yo, más que cualquiera otra obra mía, trabajo triunfante en la dimensión trágica.

¿Qué crees que debe ser la novela?

La Musa de la Novela, la última en aparecer, es la más popular de todas. Tiene algo de lo que fue vencido por ella: la épica. Aunque es evasiva, tiene mil rostros. Es también la más ambiciosa de todas. Lo quiere todo, y en los últimos cincuenta años hasta ha intentado, y en parte ha logra do, anexionarse a 
la poesía lírica (Joyce y Proust son dos ejemplos europeos; Faulkner, de los Estados Unidos; Alejo Carpentier y García Márquez, de la América Latina). La poesía, como venganza, trata de anexionarse el espíritu de la prosa (ciertos aspectos del realismo histórico de Neruda).

La novela de nuestro siglo, la que rompe con el gran realismo del siglo pasado (Balzac, Stendhal, Tolstoi) no solamente tiende a una captura total del mund o y el alma, sino que desea ser el espectador de su propia creación y experimenta fáusticamente dentro de sus propios experimentos. El estilo se inclina ante la voluntad del mito y de la magia. Si Cortázar mitifica lo psico-tráfico de sus criaturas enajenadas, hay en él una crispación sombría que proviene, diría yo, de Dostoievski. Creo que la novela actual debe su existencia a sus encuentros con lo vital social; la poesía exige lo esencial del ser existente. Alguien ha dicho que en la Divina Comedia la política es tan fundamental como la teología. La poesía quiere bajar al ágora y gritar el coloquio dramático de la historia. Pero Saint-John Perse escribe una épica interior donde lo telúrico se trenza con una simbología anónima de la historia universal. Ningún poeta podría escribir hoy un poema de movimiento exterior como The Charge of the Light Brigade, de Tennyson. Que yo sepa, no existe ningún poema importante que cante la belleza de una batalla de tanques. Marinetti, con su belicismo de superman grotesco, sólo consiguió en sus poemas de exaltación guerrera una estridencia de chatarra.

¿Cómo debe ser la novela de nuestro tiempo? No sé... Tal vez dura y compleja (Nietzsche puso en boca de Zaratustra esta frase: "Os doy una ley: haceros duros". Y recordemos que Don Segundo Sombra dice a su aprendiz de hombre: "Hacete duro, muchacho"). Tal vez de oleaje que abraza lo que asalta. ¿Peligros? Claro que los hay. Por encima de todo, creo que ha de evitar la rigidez del centurión y los dogmas del psicoanalista. Macondo es cósmicamente cotidiano. El humo de la pipa de Maigret se confunde y se mezcla con la sonrisa flotante del gato de Alicia, del gato que empieza a hacerse invisible comenzando por la cola. Una cosa es cierta, creo yo, sobre lo que debe ser una novela: ha de responder a las tres preguntas capitales: ¿Quién?; ¿Dónde? y ¿Cómo?; y conservar de alguna manera aquella virtud de interés y tensión que poseían los que narraban hechos o fábulas cerca de las protectoras hogueras, rodea- 
dos de sombra o de fieras. Habían vivido y sabían su oficio. ¿Cuál es la misión del poeta en relación con el público?

La misión del auténtico poeta sólo está comprometida con el hombre, con los trabajos y los días del hombre. La poesía moderna, fundamentalmente lírica, no tiene público, sino lectores individuales. A veces, ciertos grandes poetas tienen a todo un pueblo al norte, al sur, al este y al oeste de su alma. Cuando Neruda escribe sus Veinte poemas de amor $y$ una canción desesperada se dirige a las dos muchachas, cuyo amor había perdido, y a sí mismo. Tenía veinte años, y aquellos poemas reflejaban su crisis sentimental. Escribió una obra melancólica y estética, de emoción primaria. Diez años después, termina Residencia en la tierra, infinitamente superior a los Veinte poemas. El poeta había pasado de la melancolía a la desesperación existencial. Ahora bien: circulan, se han impreso más ejemplares (1.000.000) de los Veinte poemas que de Residencia en la tierra, que ha tenido, sin embargo, una influencia decisiva y profunda no solo en los países de habla española, sino por sus desembocaduras en la poesía del mundo.

El poeta sólo acata sus propios pensamientos y sentimientos. Se ha desvanecido la ilusión de que grandes cambios sociales podrían crear una importante poesía de raíz popular apta para millones, equidistante del sermón y el folleto político. La poesía que Antonio Machado escribió durante la guerra civil española, para responder a la magnitud heroica de su pueblo en aquellos años terribles, es floja, forzada. Pero el fusilamiento de García Lorca lo afectó profundamente, su persona se sintió directamente alcanzada, y de ese dolor íntimo surgió un poema emocionante. El poeta auténtico es siempre un hombre rico de emociones e intuiciones que más que de con-vencer trata de con-mover. Transmuta y transfiere. Es una praxis del alma, como he dicho en otra parte. El canto personal puede transformarse en un evangelio del hombre. "Me afano por la luz que canta, no por ambición ni pan", dijo Dylan Thomas. Un son que convoca puede hermanarnos. Un poema escrito en la soledad puede ser una inmensa compañía para una inmensa mayoría. En unas notas sobre mi Ecce Homo digo que "en la lengua del poeta no 
pesan bueyes muertos. Arada lengua. El canto lo hace y lo cambia: su verdad profunda le ha sido dada no de una inspiración, sino más bien de una aspiración en la cual la voz sólo colabora. La verdad es mito y el mito es verdad... La poesía llena lo que penetra: vierte en la entraña la misión de la primavera, el peso de lo eterno y la madurez del astro. Todo amor quiere la pureza de su desnudez". Y otra cosa: no se puede tocar música de Beethoven, por ejemplo, golpeando con una cuchara la chatarra de un cementerio de automóviles.

Se habla mucho de la crisis de la literatura española actual. ¿Cuál es tu opinión?

No creo en tal crisis. No es una literatura en crisis, sino de crisis. Que no es precisamente lo mismo. ¿Puede hablarse de crisis de la poesía española en lengua castellana cuando hay un poeta como Vicente Aleixandre que, a los setenta años, publica sus bellos e intensos Poemas de la consumación? Y Aleixandre no es una figura aislada: hay José Hierro, Blas de Otero, Eugenio de Nora, José Angel Valente, Carlos Bousoño y otros que aseguran vigencias hondas y palpitantes. En la novela: Delibes y Ana María Matute. En Cataluña, por otra parte, Pere Calders publica sus cuentos completos y prosigue creando; en el ensayo y la crítica avanzada descuellan Joseph N. Castellet, Joaquim Molas y Joan Fuster; entre la constelación de poetas, mencionaré a Gabriel Ferrater y Francesc Vallverdú, con su realismo histórico grávido de sentido trascendente.

¿Cuáles son las diez palabras que te gustan más?

Estoy enamorado de todas. Son el honor del hombre, dijo Valéry. En estos momentos prefiero las diez siguientes: esperanza, hombre, mujer, tú, fuego, tierra, lluvia, amor, verdad, aurora. Y pongamos una más: justicia. 